\title{
FRESH STATE PROPERTIES OF LIME MORTARS WITH FLAX OIL ADMIXTURE
}

\author{
Pavla Bauerováa ${ }^{a, b}$, Pavel Reiterman ${ }^{a, c}$, Milena Pavlíková ${ }^{b}$, \\ Magdalena Kracík ŠtorkḰ́nová ${ }^{d}$, Martin KePperT $^{a, b, *}$ \\ ${ }^{a}$ Czech Technical University in Prague, University Centre for Energy Efficient Buildings, Třinecká 1024, 27343 \\ Buštěhrad, Czech Republic \\ ${ }^{b}$ Czech Technical University in Prague, Faculty of Civil Engineering, Department of Materials Engineering and \\ Chemistry, Thákurova 7, 16629 Praha 6, Czech Republic \\ ${ }^{c}$ Czech Technical University in Prague, Faculty of Civil Engineering, Experimental Center, Thákurova 7, 16629 \\ Praha 6, Czech Republic \\ ${ }^{d}$ Art 83 Craft Mozaika, z.s., Kapitulni 103/19, 25262 Únětice, Czech Republic \\ * corresponding author: martin.keppert@fsv.cvut.cz
}

\begin{abstract}
Flax oil has been used as mortar improving, hydrophobic, admixture already in ancient times. The paper describes the identification of flax oil in mosaic mortar from ca. 1900 by help of FTIR spectroscopy. This historic mortar was reproduced by nowadays raw materials and the influence of flax oil on consistency and air entraining of fresh mortar was tested. It was found that already small amount of oil caused significant air entrainment, which, simultaneously with water repellency action, may contribute to higher durability of mortar with oil admixture. The flux oil influenced also consistency of mortar; its presence caused higher flow value of mortar. Moreover, the introduction of the paper summarizes principal knowledge about action of natural admixtures in lime mortars and plasters on basis of current literature.
\end{abstract}

KEYWORDs: Modern mosaics, flax oil admixture, consistency of fresh mortar, hydrophobic admixture.

\section{INTRODUCTION}

Mortar, plaster or even concrete on basis of lime have been used for several thousand years and most likely will be used also in future [1]. The lime based binders offer important advantages - high accessibility of raw materials, simple production technology and consequently low production costs. On the other hand, lime has obviously numerous disadvantages. One has to distinguish air lime (containing predominantly $\mathrm{CaO} / \mathrm{MgO}$ ) or hydraulic lime. Air lime is obviously non-hydraulic binder, which has to be in contact with air to set and harden. Hydraulic lime is able to reach higher strength and better durability [2]; it can be prepared by calcination of limestone with proper content of hydraulic oxides (NHL) or by mixing of lime with a pozzolanic additive (HL). All of these materials have been modified by numerous natural admixtures since ancient times in order to improve the binder performance - repellency to water, plasticity, rate of setting etc. 3. Moreover, organic fibrous materials have been used as dispersed reinforcement reducing volume changes and increasing strength and integrity of material 4. Nowadays, the application of synthetic organic admixtures (i.e. better defined, more effective, with higher stability) is dominant in engineering practice, nevertheless the studying of natural admixtures has an importance with respect to restoration works or possibly may contribute to higher sustainability of building structures.
The natural species used historically as lime admixtures can be classified, according to their chemical nature, to three groups: proteins, polysaccharides and triglycerides (glycerin esters of fatty acids, i.e. oils and fats,). Specifically, protein admixtures were caseins (curd, buttermilk, whey), collagens (animal glue) and egg proteins [5]. Animal glue was found to increase the mortar's strength significantly; the mechanism probably lies in refinement of pore system and reduction of total porosity [3]. Egg was used as plasticizer and setting retarder 6]; egg white (optimum content $6 \%$ by lime) increased plasticity, strength and reduce water absorption [7]. Casein containing admixtures improve workability and strength; casein forms in lime environment calcium caseinate, which is insoluble and acts as binder [8, 9. Animal blood can be also classified as protein admixture, even though its complex composition; it is significantly improving adherence of lime mortar and its durability due to reduction of water absorption and air-entraining effect [10].

The ancient polysaccharide admixture is opuntia powder (or mucilage). It increases the rate of carbonation of lime, what obviously results to faster hardening of mortar [3]. Nowadays, derivatives of natural polysaccharides cellulose ethers, welan gum, diutan gum, guar gum, xanthan gum are widely used as Viscosity-enhancing admixtures, increasing viscosity, cohesion and stability of mortars 11. Influence of starch on lime mortar was found to be dependent on its 
dosage; it acted as a thickener when the incorporated dosage was up to $0.30 \%$ of lime weight; conversely, above that dosage, it behaved as a plasticizer [12]

Triglycerides admixtures are represented e.g. by olive oil; it reduced the porosity as well as pore size resulting to lower permeability of mortar 3 . Thanks to their structure, triglycerides are also acting as hydrophobic admixture. Linseed oil acted as absorption reducer (and durability enhancer), but without a large influence on pore system [13. Nowadays, the fatty acids are used as water repellant admixtures in form of soaps (e.g. calcium stearate) [14].

The present paper deals with influence of flax (linseed) oil on fresh state properties of lime based mortar. The direct motivation for this research lies in fact, that flax oil was identified in a sample of historical mosaic mortar; the flax oil identification is described as well.

\section{EXPERIMENTAL}

The initial material under study, inspiring the present experimental work, was a sample of mosaic mortar collected at Peluněk sepulcher, Malvazinky cemetery, Prague. It was built round 1900. The sample of mortar was characterized by XRD (PAnalytical Empyrean, $\mathrm{Cu}_{\mathrm{K} \alpha}$ source); the content of filler insoluble in acid (i.e. quartz and silicates) was determined by help of 1:3 $\mathrm{HCl}$ dissolution and filtration. The historic mortar was also examined by SEM (Zeiss Merlin). The oil admixture was identified by help of FTIR spectroscopy (Nicolet 6700) in extract of mortar (extraction 1:10 by chloroform).

The reproduced mosaic mortar was prepared on basis of analysis of the historical mortar from sepulcher. Lime hydrate was used as the principal binder (40\%), as the filler were used three fractions: quartz $0-0.5 \mathrm{~mm}$ $(30 \%)$ and $0.5-1 \mathrm{~mm}(10 \%)$ and milled limestone D8 (20\%). The water/lime ratio was kept constant (0.87). The natural flax oil was dosed as admixture (0-10\% by lime hydrate weight). The first step of mixing procedure [15] was homogenization of dry powders by help of electric mixer; than small amount of powder was mixed separately with oil and this paste was dispersed in the rest of dry powders. Finally the water was added. The consistency and entrained air content of mortar was measured by standard procedures (EN 1015-3 and 7) by help of flow table test and pressure type air content meter.

\section{RESUlts AND DisCUSSION}

Characterization of historic mortar: The sample of historic mosaic mortar was examined by XRD (Fig. 1). It revealed that the main phases are quartz and calcite; the used filler also introduced muscovite and albite to the mortar. Surprisingly, in sample of age of 120 years, also portlandite was found. Its presence was confirmed by thermal analysis as well. The results of thermal analysis also indicated, that the binder was closer to the air lime than to the hydraulic one, although EDX analysis indicated some Si and Al atoms dispersed in binder phase. The residuum after acid dissolution of the sample was $15 \%$; this amount thus may be attributed to siliceous filler. Unfortunately, the amount of historic mortar sample was limited (ca $10 \mathrm{~g}$ ) due to conservation of historic mosaic and thus this result cannot be assumed as fully representative; neither the granulometry of filler cannot be determined reasonably. Nevertheless, visually one can sate that the mortar does not contain particles larger than $1 \mathrm{~mm}$ (these would, obviously, make difficult the application of mosaic mortar). The SEM (and EDX) analysis shown, that besides siliceous filler, the mortar contains also calcite (marble) flour with size of particles in the range of a few of tenths microns (Fig. 2).

The carbonate dissolution liberated not only the siliceous aggregates, but also an unknown organic substance forming a brownish greasy layer on the filter paper. In order to identify this substance, $5 \mathrm{~g}$ of mortar powder was extracted by chloroform $(50 \mathrm{ml})$. The obtained extract was analyzed by FTIR spectroscopy (Fig. 3). The spectrum was compared with nowadays flax stand oil. The group of three signals around $2900 \mathrm{~cm}^{-1}$ belongs to $\mathrm{C}=\mathrm{C}$ groups; in this case in fatty acids. Flax oil triglycerides contain three unsaturated fatty acids - triply unsaturated $\alpha$-linolenic acid, doubly unsaturated linoleic acid and monounsaturated oleic acid. The peak at $1758 \mathrm{~cm}^{-1}$ in reference stand oil corresponds to $\mathrm{C}=\mathrm{O}$ in esters (i.e. triglycerides); the shift $1709 \mathrm{~cm}^{-1}$ in extract is due to decomposition of triglycerides to Ca-soaps of carboxylic acids and glycerol in basic environment of mortar. The peak at $1465 \mathrm{~cm}^{-1}$ belongs to $-\mathrm{CH}_{2}-$ groups in acids, while the peaks in range $1000-1400 \mathrm{~cm}^{-1}$ are due to $\mathrm{C}-\mathrm{O}$ bonds in glycerol. The FTIR results can be understood as proof that flux oil was used as admixture in historic mosaic mortar. The quantification of organic substance in mortar was attempted on base of mass balance of the extraction experiment; the result was ca. $6 \%$ what seems to be a lot and reasonability of such high dosage of flax oil must be checked in future experiments with reproduced mortars.

Influence of flax oil on fresh state properties of reproduced mortar was tested in wide range of oil dosing ( $0-10 \%$ by lime weight) (Fig. 4). The consistency of reference mortar was $130 \mathrm{~mm}$, what is less than 140-200 mm, what is range of "plastic mortar". In fact, the mortar is usually mixed for $160 \mathrm{~mm}$ consistency. Nevertheless, this initial (low) choice of mixing water amount was due to possibility to study the oil influence on consistency. The oil dosage generally increased the flow value, but even the very high dosage (10\%) did not caused any unacceptable behavior of fresh mortar. The observed trend is opposite compared to publications [8, 15] where the reduced flow is explained by hydrophobicity of the oil and consequent low absorption of water to particles. In our opinion, this effect should on contrary increase the flow value 


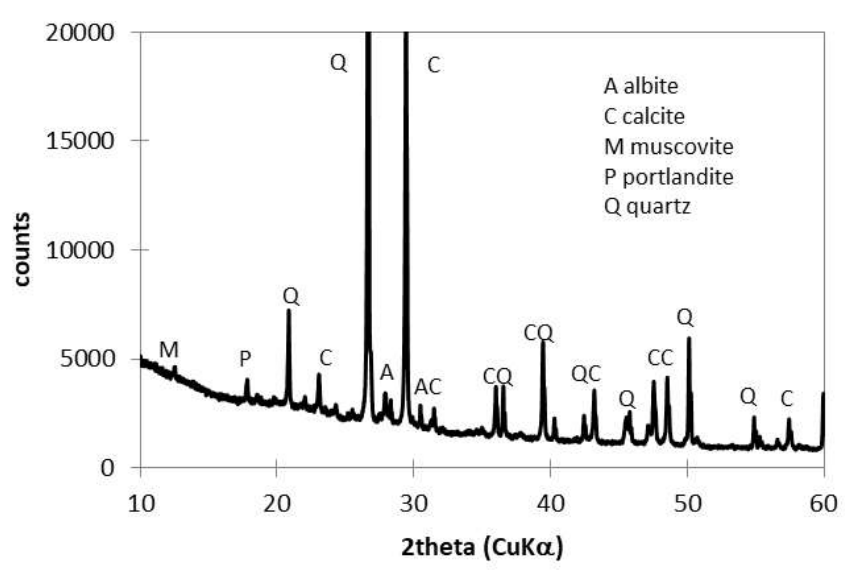

Figure 1. X-ray diffractogram of historic mortar.

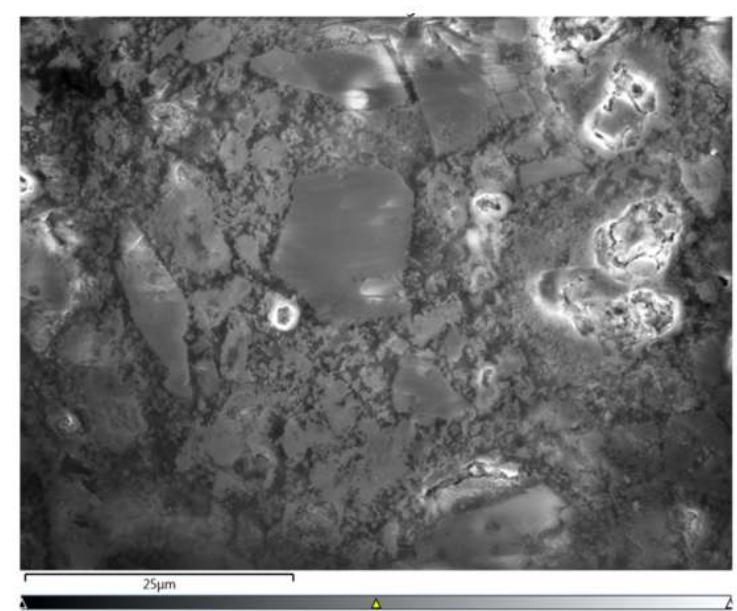

FiguRE 2. SEM of historic mosaic mortar.

(at constant water content), since the mixing water is less adsorbed by particles of lime and thus reduces more effectively the mortar stiffness.

The air content of reference mortar was ca. $2 \%$, what is expectable value for lime mortar. Already $0.5 \%$ of flax oil doubled the air content, while the further increasing doses did not have such significant effect and the value remained around 4-5\%. As the air entraining admixtures are conventionally used various surfactants [16], nevertheless also oils are able to increase the air content and slump of concrete [17]. The content of entrained air in a binder is closely related to the viscosity - higher air content means lower viscosity [18, i.e. higher result of flow table test, as it was indicated by the present results.

\section{Conclusions}

Flax oil admixture was identified by FTIR spectroscopy in the sample of historic mortar from Peluněk sepulcher, built around 1900 in Prague Malvazinky cemetery. The composition of this historic mortar was reproduced; the effect of wide range of dosing of flax oil on fresh state properties of mortar was tested experimentally. The oil admixture caused increase of flow value as well as entrained air content. These findings are in agreement with results published on behavior of oil in concrete. Moreover the oil is inducing hydrophobic behavior of the mortar. The higher air content and hydrophobicity of mortar are supposed to be responsible for the improved durability of flax oil mortars reported in literature. 


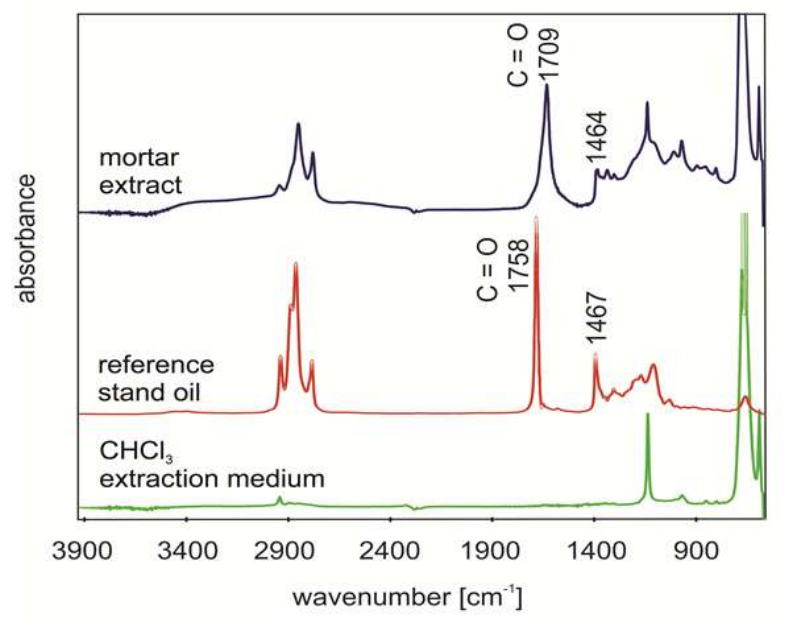

FIGURE 3. FTIR spectra of extract, reference oil and extraction medium.

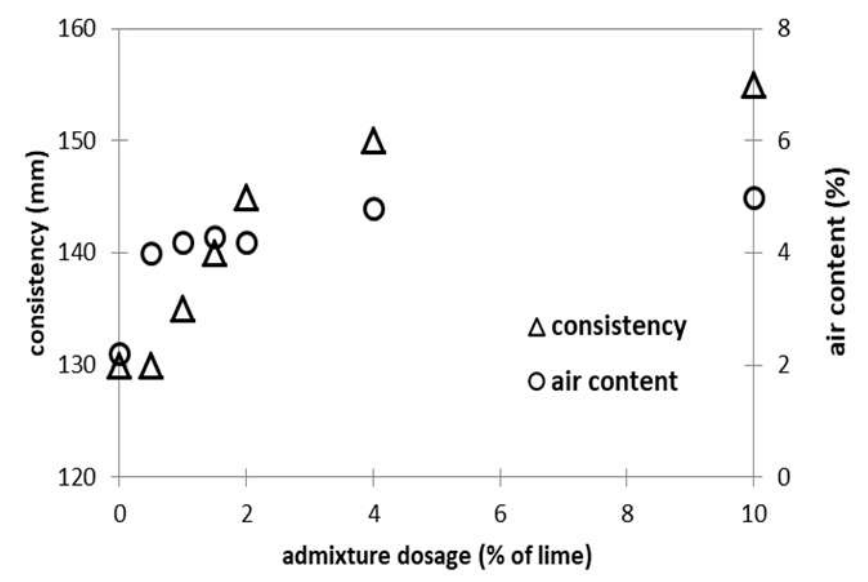

Figure 4. Influence of flax oil admixture on consistency (flow table test) and air content of reproduced mortars.

\section{ACKNOWLEDGEMENTS}

The work has been supported by Czech Science Foundation project Nr. 18-13525S "Modern mosaic mortars in a microscope - methods for their materials characterization and degradation studies".

\section{REFERENCES}

[1] M. Stefanidou, V. Pachta, S. Konopissi, et al. Analysis and characterization of hydraulic mortars from ancient cisterns and baths in Greece. Materials and Structures 47:571-580, 2014. DOI:10.1617/s11527-013-0080-y.

[2] K. Dvořák, I. Hájková. The effect of high-speed grinding technology on the properties of fly ash. Materiali in tehnologije 50:683-687, 2016. DOI:10.17222/mit.2015.127.

[3] L. Ventolà, M. Vendrell, P. Giraldez, L. Merino. Traditional organic additives improve lime mortars: New old materials for restoration and building natural stone fabrics. Construction and Building Materials 25:33133318, 2011. DOI:10.1016/j.conbuildmat.2011.03.020.

[4] C. Kennedy, W. A Revie, L. Troalen, et al. Studies of hair for use in lime plaster: Implications for conservation and new work. Polymer Degradation and Stability 98:894898, 2013. DOI:10.1016/j.polymdegradstab.2013.01.004

[5] I. Krizova, J. Schultz, I. Nemec, et al. Comparison of analytical tools appropriate for identification of proteinaceous additives in historical mortars. Analytical and Bioanalytical Chemistry 410:189-200, 2018. DOI:10.1007/s00216-017-0709-8.

[6] R. Nogueira, A. P. Ferreira Pinto, A. Gomes. Design and behavior of traditional lime-based plasters and renders. Review and critical appraisal of strengths and weaknesses. Cement and Concrete Composites 89:192204, 2018. DOI:10.1016/j.cemconcomp.2018.03.005

[7] M. A. Othuman Mydin. Preliminary studies on the development of lime-based mortar with added egg white. 
International Journal of Technology 8(5):800-810, 2017. DOI:10.14716/ijtech.v8i5.442

[8] P. Rovnaníková. Omítky. STOP Praha, 2002.

[9] S. Kuckova, M. Krizkova, L. Vankova, et al. Towards proteomic analysis of milk proteins in historical building materials. International Journal of Mass Spectrometry 284:42-46, 2009. DOI:10.1016/j.ijms.2009.01.011.

[10] S. Q. Fang, K. Zhang, H. Zhang, B. Zhang. A study of traditional blood lime mortar for restoration of ancient buildings. Cement and Concrete Research 76:232-241, 2015. DOI:10.1016/j.cemconres.2015.06.006

[11] M. Vyšvařil, T. Žižlavský. Effect of chitosan ethers on fresh state properties of lime mortars. IOP Conference Series: Materials Science and Engineering 251:012039, 2017. DOI:10.1088/1757-899X/251/1/012039

[12] A. Izaguirre, J. Lanas, J. Álvarez. Behaviour of a starch as a viscosity modifier for aerial lime-based mortars. Carbohydrate Polymers 80:222-228, 2010. DOI:10.1016/j.carbpol.2009.11.010.

[13] C. Nunes, Z. Slížková. Freezing and thawing resistance of aerial lime mortar with metakaolin and a traditional water-repellent admixture. Construction and Building Materials 114:896-905, 2016. DOI:10.1016/j.conbuildmat.2016.04.029.
[14] A. Izaguirre, J. Lanas, J. Álvarez. Effect of waterrepellent admixtures on the behavior of aerial lime-based mortars. Cement and Concrete Research 39:1095-1104, 2009. DOI:10.1016/j.cemconres.2009.07.026

[15] C. Nunes, Z. Slížková. Hydrophobic lime based mortars with linseed oil: Characterization and durability assessment. Cement and Concrete Research 61-62:2839, 2014. DOI:10.1016/j.cemconres.2014.03.011.

[16] G. Liu, L. Chen. Development of a new type of green switch air entraining agent for wet-mix shotcrete and its engineering application. Advances in Materials Science and Engineering 2016:1-9, 2016. DOI:10.1155/2016/6981091

[17] B. Hamad, A. A. Rteil, M. El-Fadel. Effect of used engine oil on properties of fresh and hardened concrete. Construction and Building Materials 17:311-318, 2003. DOI:10.1016/S0950-0618(03)00002-3

[18] F. Cardoso, V. John, R. Pileggi. Rheological behavior of mortars under different squeezing rates. Cement and Concrete Research 39:748-753, 2009. DOI:10.1016/j.cemconres.2009.05.014. 